<ショート・ペーパー>

\title{
熱赤外波長域における水蒸気透過特性の簡易モデル
}

花 泉 弘*.藤 村 貞 夫* ・椿 広 計*.豊田弘 道*

\section{A Simplified Water Vapor Transmission Model in the Thermal Infrared}

Hiroshi Hanaizumi*, Sadao Fujimura*, Hiroe Tsubaki* and Hiromichi Toyota*

1.はじめに

従来, 吸収体の赤外線透過特性は, 狭波長帯におけ る分光吸収係数の平均値とそれを吸収体の量や温度, 圧力に応じてその波長帯での透過率に結びつけるモデ ルとで与えられていた . そのため，てれらを用い て，使用する放射計の観測波長帯での透過特性を求め ようとすると，モデル自体が複雑な上江数值積分を必 要とするため, 見通しが悪く取扱いす不便であった.

ての問題を解決するため，乙こでは放射計の観測波 長帯における吸収体の透過特性を指数関数の和で近似 する簡易モデルを提案する．てのモデルは，吸収体の 分光透過特性を放射計の波長帯での透過特性に拡張す るあのであるが，加え合わせる項数が少ないため，簡 便で取扱いが容易なととが特長である。

以下に，透過特性の測定法および簡易モデルとその 評価について述べる.

\section{2. 吸収体の透過特性}

散乱がなく局所熱力学的平衡が成立する光路を通し て測定される (擬似) 黒体の分光放射輝度は放射伝達 方程式で記述でき2)，さらにそれを簡単化することに よって使用波長帯（ $\lambda_{1} \sim \lambda_{2}$ と考える）における測定モ デル

$$
L_{o}=\tau L_{t}+(1-\tau) L_{p}
$$

を得る ${ }^{3)}$. こてで， $L_{o}$ は測定される放射輝度を表わ

†第 7 回リモートセンシングシンポジウムで発表 (昭 56 . 11)

* 東京大学工学部 東京文京区本郷 7-3-1

* Faculty of Engineering, The University of Tokyo, Bunky-ku, Tokyo

(Received June 1, 1985)

Key Words: thermal infrared, transmittance, simplified model, absorption coefficient, precipitable water
し， $L_{t}$ は観測に用いる（擬似）黒体（温度 $T_{t}$ ）の放 射輝度, $L_{p}$ は光路上吸収体の実効温度 $T_{p}$ に対応す る黒体の放射輝度を表わす．また，透過率ては

$$
\tau=\frac{\int_{\lambda_{1}}^{\lambda_{2}} \tau_{\lambda}\left(L_{t \lambda}-L_{p \lambda}\right) d \lambda}{\int_{\lambda_{1}}^{\lambda_{2}}\left(L_{t \lambda}-L_{p \lambda}\right) d \lambda}
$$

で与えられる.（2)式で添字入は分光放射輝度を意味 し, $\tau_{\lambda}$ は分光透過率で, 光路長を $Z$ とするとき,

$$
\tau_{\lambda}=\exp \left\{-\int_{0}^{Z} k_{\lambda} \rho(l) d l\right\}
$$

と表わせる.（3)式で $\rho(l)$ は光路に沿った吸収体の 密度分布を表わす. 分光吸収係数 $k_{\lambda}$ は一般に温度と 圧力によっても変化するので $\int_{0}^{Z} k_{\lambda} \rho(l) d l=\bar{k}_{\lambda} \int_{0}^{Z} \rho(l) d l$ $=\bar{k}_{\lambda} Q$ と扔くことにより，(2) 式と(3) 式加ら使用波 長帯での透過特性

$$
\tau(Q)=\int_{\lambda_{1}}^{\lambda_{2}} w_{\lambda} \exp \left(-\bar{k}_{\lambda} Q\right) d \lambda
$$

を得る.ここで， $Q$ は光路上吸収体量 ${ }^{1)}$ であり， $\bar{k}_{\lambda}$ は 実効的な分光吸収係数である. また， $w_{\lambda}=\left(L_{t \lambda}-L_{p \lambda}\right) /$ $\int_{\lambda_{1}}^{\lambda_{2}}\left(L_{t \lambda}-L_{p \lambda}\right) d \lambda$ である. $\int_{\lambda_{1}}^{\lambda_{2}} w_{\lambda} d \lambda=1$ なので，透過特 性 $\tau(Q)$ は指数関数の重み付き平均の形で与えられる ことがわかる.

ここで提案するモデルは，(4)式の関係をできるだ け少ない項数 $n$ で

$$
\tau(Q)=\sum_{i=1}^{n} w_{i} \exp \left(-k_{i} Q\right)\left(\sum_{i=1}^{n} w_{i}=1\right)
$$

と近似するむのである。一般に， $n$ が大きければ大き いほじ近似の精度は向上するが，ての測定值に誤差が 含まれ測定值の数が限られる場合には，ある $n$ の值で 最良の近似が得られる(注 1)。

（注 1 ） 測定点における残差は $n$ が大きくなると小さくなる が，それらの間の值での近似の精度は逆に悪くなる. 


\section{3. 水蒸気透過特性の測定}

温度分布および吸収体密度分布が一様な（気温, 湿 度の安定な）室内光路の光路長を変えて水蒸気透過特 性を測定した．また，測定した透過特性が正しいかど うか評価するために，乙れとは別に一定長の吸収セル 内の相対湿度を変化させて透過特性を測定し，両者を 比較した.

\section{1 可変長光路による測定（手法 1 )}

Fig. 1 に示す配置で, $300 \times 300 \mathrm{~mm}^{2}$ の水楔状空洞 を光路長を変えながら観測した．乙のとき，光路に沿 って配置した 5 本の水銀棒温度計（気象庁検定済，放 射シールド付）を用いて測定した温度の平均值を光路 上水蒸気温度 $T_{p}$ として $L_{p}$ を算出し, $(1)$ 式を変形

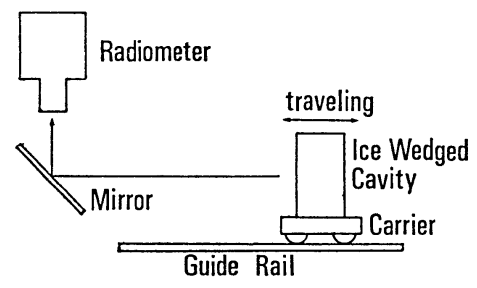

Fig. 1 Measurement system for path transmittance

Table1 Relative humidity by salt solutions (at $20^{\circ} \mathrm{C}$ )

\begin{tabular}{|c|c|c|}
\hline \multicolumn{3}{|c|}{ 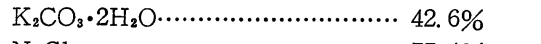 } \\
\hline $\mathrm{NaCl}$ & .......................... $75.4 \%$ & \\
\hline $\mathrm{KCl}$ & 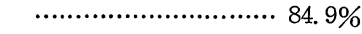 & \\
\hline $\mathrm{KNO}_{3}$ & ........................... 93.8\% & \\
\hline \multicolumn{3}{|c|}{ 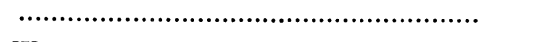 } \\
\hline Water & 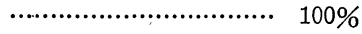 & \\
\hline
\end{tabular}

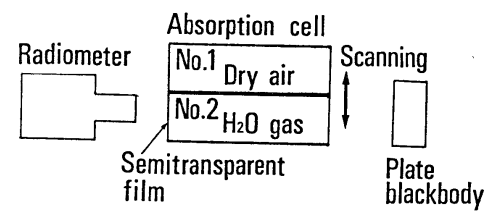

Fig. 2 Measurement system for cell transmittance

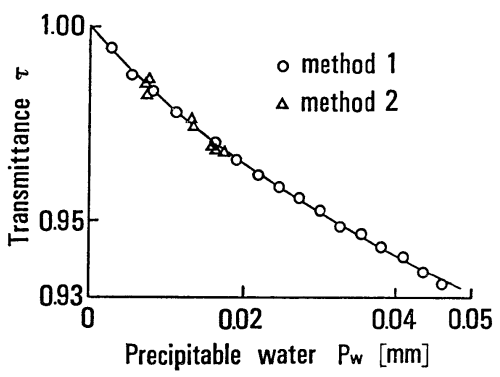

Fig. 3 Transmittance of water vapor
した

$$
\tau=\frac{L_{o}-L_{p}}{L_{t}-L_{p}}
$$

によって透過率を求めた. なお， 反射鏡の直前での透 過率が 1 となるように予め放射計を校正しておき, 測 定は光路に与える影響を最小限にするために氷楔状空 洞を近づけながら行った. また，測定した透過率を水 蒸気量と対応づけるため, (株) エース研究所製鋭感湿 度計(校正済)を用いて光路の相対湿度を測定した。

\section{2 吸収セルを用いる測定（手法 2 ）}

内部に調湿液を入れ両端を半透明膜で密閉した測定 セルを安定な室温中に長時間放置した後に，てれを通 して放射輝度 $L_{t}$ の擬似黒体を観測する場合にむ，得 られる観測值は (1) 式で表せる。乙のときの透過率を $\tau_{m}$ とすると， $\tau_{m}$ は擬似黒体から放射計までの透過率 を表すむので，セル外光路水蒸気やセル両端の半透明 膜などの不要な透過率む含まれる，これらの影響を消 去するため, 内部をシリカゲルで乾燥させた基準セル （内部の透過率を 1 と見なす）についての透過率 $\tau_{s}$ で 正規化して測定セル内光路に対応する透過率 $\tau_{p}$ とし た.

測定には内面を黒化し両端を斜めた切断したアルミ 板製の筒 $\left(930 \times 240 \times 240 \mathrm{~mm}^{3}\right)$ の中に, Table 1 に示 す調湿液 ${ }^{4)}$ むくはシリカゲルに入れて，ポリ塩化ビ ニリデン膜で密閉したセルを用い，Fig. 2 に示すよ うに，二つのセルを交互に透過して氷楔状空洞と室温 黒体板とを観測し，それぞれに対応して得られる観測 值 $L_{01}^{m}, L_{02}^{m}$ (測定セル)， $L_{01}^{s} L_{02}^{s}$ (基準セル) を用いて 透過率

$$
\tau_{p}=\frac{L_{01}^{m}-L_{02}^{m}}{L_{01}^{s}-L_{02}^{s}}
$$

を求めた。

\section{3 測 定 結果}

Fig. 3 亿手法 1 亿よる水蒸気透過特性の測定結果 (“○”)と手法 2 による結果 (“公”) とを示す．とこで, 横軸は大気圧を 1 気圧として光路温度と相対湿度から 求めた ${ }^{5)}$ 光路上の水蒸気量 (Precipitable water) ${ }^{6)}$ 表わしている. 両手法による結果はよく一致してお り, 得られた水蒸気透過特性の正しいてとがわかる. なお，手法 2 による透過率測定值のばらつきが大きい のは，七ル 内光路の 透過率 $(\tau \simeq 1 \sim 0.96)$ に対して外 部光路および半透明膜の透過率 $(\tau \simeq 0.45)$ が低く，测 定の $S / N$ が悪かったととによる.

\section{4. 簡易モデルによる水蒸気透過特性の記述}

ここでは，手法1による測定結果（Fig. 3 “○”）に 
Table 2 Parameters of each models Weights $w_{j}$, absorption coefficients $k_{j}\left[\mathrm{~mm}^{-1}\right]$ and cumulative contribution factors $\mathrm{CCF}$

\begin{tabular}{c|l|r|c}
\hline$n$ & \multicolumn{1}{|c|}{$w_{j}$} & \multicolumn{1}{c}{$k_{j}$} & CCF \\
\hline 1 & 1.00 & 1.60 & 0.967 \\
\hline \multirow{2}{*}{2} & 0.979 & 1.03 & 0.9993 \\
& 0.021 & 67.37 & \\
\hline \multirow{3}{*}{3} & 0.979 & 1.03 & \\
& $8.6 \times 10^{-19}$ & 37.54 & 0.9993 \\
& 0.021 & 67.37 & \\
\hline
\end{tabular}

$Q=P_{w}$ として $(5)$ 式に示すモデルのあてはめを行う.

Table 2 に, 非線形最小 2 乗法を用いて $n=1 \sim 3$ の モデルをあてはめた場合の係数を示す．また， $n=3$ としたときにモデルから得られる透過特性を Fig. 2 中の実線で示す.

Table 2 を見ると, $n=3$ の場合には事実上 $w_{2}=0$ となっておりり, 透過特性が $n=2$ とするモデルで十分 記述できるとと，さらに累積寄与率が 0.9993 であっ たととから非常に精度の高い近似となっていることが わかる，測定に用いた 6〜9 $\mu \mathrm{m}$ 帯は，水蒸気の吸収 帯を含みながら大気の空にもかかっているため分光吸 収係数は複雑に変化しているが, Table 2 の結果はそ れが二つの吸収係数で代表できることを示している.

\section{5. おわりに}

放射計の観測波長帯における光路上吸収体の透過特
性を指数関数の和で近似する簡易モデルを提案した. このモデルは，加え合わせる指数関数の項数の少ない ことが特長であるが，てれによって観測波長帯での透 過特性が簡易な関数で表わせるため，透過率から吸収 体量を求めたり大気効果を解析するのに便利である.

実際に 6 9 $\mu \mathrm{m}$ 帯で測定した水蒸気の透過特性に ここでのモデルをあてはめたところ，乙の波長帯では 分光透過特性が複雑であるにあかかわらず，二つの指 数関数の和で透過特性が精度よく近似できた. 何故二 つの指数関数の和でよいのかの理論的解析や一般の波 長帯への拡張性についての検討は今後の課題である.

\section{参 考 文 献}

1) W. L. Wolfe and G. J. Zissis (Ed.): The Infrared Handbook, ERIM (1978)

2) S. Chandrasekhar: Radiative Transfer, Dover (1960)

3) C. Prabhakara, G. Dalu and V. G. Kunde: Estimation of Sea-Surface Temperature from Remote Sensing in the 11 to $13 \mu \mathrm{m}$ Window Region, J. Geophys. Res. 79-33, 5039/5044 (1974)

4) 高分子学会編：材料と水分ハンドブック, 共立出版 (1968)

5) 工業計測技術体系編集委員会編：湿度，水分測定， $1 / 7$, 日刊工業新聞社 (1968)

6) たとえば, R.D. Hudson, Jr.: Infrared System Engineering, 114/117, Wiley (1969) 